\section{BA Institute of \\ YK Business Administration \\ 六下 \\ Karachi \\ Leadership and Ideas for Tomorrow}

Article 4

\section{Business Review}

\author{
Volume 12 Issue 2
-December 2017 \\ Volume 12 Issue 2
July-December 2017
}

\title{
Route optimization for the cement industry under the CPEC initiative
}

\author{
Moez Munir \\ Institute of Business Administration, Karachi, Pakistan \\ Rameez Khalid \\ Institute of Business Administration, Karachi, Pakistan \\ Muhammad Latif \\ School of Engineering, Manchester Metropolitan University, Manchester, UK
}

Follow this and additional works at: https://ir.iba.edu.pk/businessreview

\section{(c) (1)}

This work is licensed under a Creative Commons Attribution 4.0 International License.

\section{Recommended Citation}

Munir, M., Khalid, R., \& Latif, M. (2017). Route optimization for the cement industry under the CPEC initiative. Business Review, 12(2), 65-83. Retrieved from https://doi.org/10.54784/1990-6587.1043

This article is brought to you by iRepository for open access under the Creative Commons Attribution 4.0 License and is available at https://ir.iba.edu.pk/businessreview/vol12/iss2/4. For more information, please contact irepository@iba.edu.pk. 


\title{
Route optimization for the cement industry under the CPEC initiative
}

\author{
Moez Munir • Rameez Khalid . \\ Muhammad Latif
}

\begin{abstract}
The China-Pakistan Economic Corridor (CPEC) initiative envisages substantial infrastructure development in Pakistan. This study ascertains optimal transportation routes for the cement industry under the CPEC program using a mixed integer linear programming model and discrete-event simulation using Witness simulation software. The solution of the mathematical model presents the best combination of cement manufacturing clusters, road interchanges and ports to connect. Policy makers and practitioners can use the findings of this study to optimize logistics decisions under CPEC.
\end{abstract}

Keywords China Pakistan Economic Corridor · Interchange location · Mixedinteger linear optimization · Discrete-event simulation · Witness modeling

\section{Introduction}

The world has become a global village with the advent and advancement of technology. One of the earliest technologies was a road or a path or a route, more specifically 'a trade route'. These road networks enhanced communication and then rail, air and electronic channels were further developed. These advancements made living more comfortable but simultaneously busier.

Pakistan, a developing country, will soon be listed in the fastest growing economies after the construction of advanced road network routes under the China-Pakistan Economic Corridor (CPEC) Finance (2016). The development of western, central and eastern routes is central to CPEC, i.e. from Gwadar (Pakistan) to Kashghar (China). The CPEC project, a part of One Belt One Road (OBOR) strategy of China, is considered a game changer for Pakistan

Moez Munir

Institute of Business Administration, University Road, Karachi-Pakistan

Rameez Khalid

Institute of Business Administration, University Road, Karachi-Pakistan

E-mail: rameezkhalid@iba.edu.pk

Muhammad Latif

School of Engineering, Manchester Metropolitan University, Manchester, UK 
and the region. It will not only result in the creation of infrastructure but will also generate employment opportunities Abid and Ashfaq (2015). Highways are pivotal for Pakistan. They account for $96 \%$ of the freight transportation and only $4 \%$ is moved through railways Finance (2016). Ironically, Pakistan has weak highway infrastructure. Highways account for only $3 \%$ of the entire road network, freight journeys are 2-4 times longer than in Europe, and, 4-6\% of GDP is lost annually due to logistical inefficiencies Mohmand and Wang (2013). CPEC's routes can fill this gap, however, projects of this scale and magnitude do not come without challenges.

Emerging economies are characterized by insufficient use of quantitative approaches in decision-making. Even if these approaches are used, foreign support is usually sought Mudroch (1999). Furthermore, current literature Bengali (2015) Javaid (2016) Sial (2014) Abid and Ashfaq (2015) mostly discusses CPEC at the macro-level and there is a dearth of sectoral research. Quantitative approaches can therefore, help in strategic, tactical and operational level decision making particularly under CPEC's highway projects, for determining:

(1) potential locations and capacities of highways (alignment Shahfahi and Bagherian (2013), and number of lanes), interchanges, ports and Special Economic Zones (SEZs);

(2) configuration of national logistics network;

(3) forecasted locations and gravity of congestion, accidents Mitra (2016) Bolapragada et al (2016) and floods (or force majeure);

(4) cheapest, quickest and shortest routes according to industrial sectors and zones;

(5) the optimal mix of multi-modal transportations;

(6) rationalizations of highway construction investments and returns;

(7) traffic rules for better management in developing efficient and safer highways

Li and Chow (2015), and

(8) impact of decisions on costs of land acquisition, construction, Right of Way (ROW), tariff, toll Gonzalez Velarde et al (2015), transportation and fuel etc.

The objective of this study is to primarily present an application of selected quantitative approaches to optimize CPEC's routes. The secondary objective is to suggest better locations of interchanges on the proposed CPEC's Eastern Route (CPEC-ER). This can further validate the locations of already suggested interchanges in the CPEC plan. Central and western routes are beyond the scope of this research.

These interchanges are proposed considering the case of the cement industry. The multi-methodological approach starts with the application of 'mixed-integer linear programming' (MILP) followed by a 'discrete-event simulation' (DES). MILP is applied to CPEC considering it as a standard location-routing problem (LRP) Prodhon nad Prins (2014), however, this paper further creates a What-if scenario for this problem using DES. Simulation is carried out on a powerful software package 'Witness', which is an industry standard for modeling and simulating complex systems Lanner (2016).

Policy makers and practitioners can use the analytical findings of this study in optimizing logistics and highway relevant decisions under CPEC. The next section will present the context of the study and discuss the facets of CPEC 
and the cement industry relevant to this research. The subsequent section will discuss the research methodology. Next, we will present the mathematical and simulation models applied to CPEC-ER. This will be followed by an analysis of the results, conclusion and proposed areas for future research.

\section{Context}

This section will first discuss the salient features of the CPEC project and then present its various perceived benefits and challenges. It will end with a brief introduction of Pakistan's cement industry.

\subsection{China Pakistan Economic Corridor (CPEC)}

CPEC is a portfolio of USD 46 billion worth of projects that will transform Pakistan into a central hub for trade (2016c). It includes projects relevant to energy, road, and rail etc. Under CPEC, Gwadar Port (Balochistan, Pakistan) will be connected to Kashghar (Xinjiang, China) via three highway routes i.e. western, central and eastern. It will allow Pakistan to export locally produced goods Market research provider (2017), and to increase the Foreign Direct Investment (FDI) flow up to USD 46 billion from USD 1.8 billion in 2014 Markey and West (2016).

China will invest 170 billion yuan for the construction of the road network

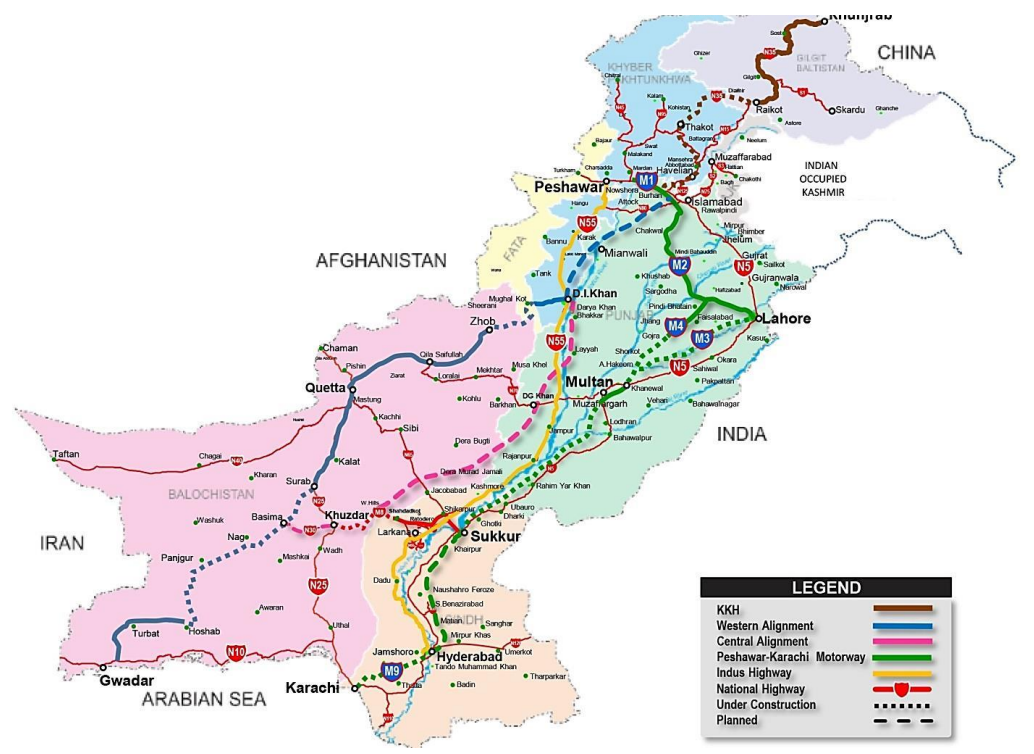

Fig1: Map of National Highway Network (NHA, 2017)

Business Review: (2017) 12(2):65-83 
of the CPEC routes (2017). The CPEC-ER is about 2,395 km long Finance (2016) which is the longest as compared to western and central routes Bengali (2015), and has 6 lanes, 3 on each side. In our study, as per one interviewee, it is 2,769 km long. Figure 1 shows the suggested alignment of CPEC-ER (Khunjrab to Gwadar through Peshawar Karachi Motorway PKM). Table 1 highlights the additional features of this route.

China will also construct 27 Special Economic Zones (SEZs) under CPEC. Three of these SEZ's will be in Sindh, seven in Punjab and one over an area of 3000 acres in Gwadar by the end of December, 2017 (2016b). China will also build an oil refinery at Gwadar, which will transport 17 million barrels of oil per day (2016a) using these routes and pipelines Calabrese (2014).

Table 1: Travelling distances on the eastern alignment in km (NHA, 2017)

\begin{tabular}{lr}
\hline Northern Route & 784 \\
Khunjrab-Raikot & 335 \\
Raikot-Thakot & 270 \\
Thakot-Havelian & 120 \\
Havelian-Burhan & 59 \\
Peshawar-Karachi Motorway (PKM) & 1512 \\
Peshawar-Islamabad & 155 \\
Islamabad-Pindi Bhattian & 235 \\
Pindi Bhattian-Multan & 298 \\
Multan-Sukkur & 392 \\
Sukkur-Hyderabad & 296 \\
Hyderabad-Karachi & 136 \\
N-10 Makran coastal Liari-Ormara- Gwadar-Jiwani & 653 \\
N-25 Karachi-Kalat-Quetta-Chaman & 813 \\
\hline
\end{tabular}

\subsection{CPEC: Benefits and challenges}

Since CPEC's inception, numerous authors have discussed its benefits and challenges for Pakistan, a summary of which is presented in table 2. A common theme when considering benefits is infrastructure development, whereas, security related threats comes across as the major challenges. CPEC has the potential to boost the GDP of Pakistan at an annual growth rate of $2 \%$ Ramay (2016). Mostly, these studies discuss CPEC at a strategic-level and are qualitative in nature. Moreover, majority of the studies have approached CPEC from socio-economic and geo-political perspectives at the macro-level presenting analyses similar to Strength-Weakness-Opportunity-Threat (SWOT) and Political-Economic-Social-Technological-Legal-Environmental (PESTLE).

Quantitative, tactical and operational level, and sectoral studies are rare. One reason for this is that CPEC is in its inception phase, and as such data and issues are relatively unknown. Ahmed and Mustafa (2014) identified the 
relationship between strategic level policy decisions and the associated operational level impacts for the agriculture sector, however, conceptual frameworks are required to bridge this gap. Similarly, Zhang and Shi (2016) discussed the macro and micro-level risks and benefits of CPEC.

Studies similar to Sheu and Kundu (2017), who conducted a research for OBOR's logistics network, can be benchmarked for CPEC. Our study presents a case for reducing transportation costs for the cement sector using quantitative methods by gathering operational level details through interviews. This data then becomes the input for mathematical and simulation models.

Table 2: CPEC's benefits and challenges for Pakistan

\begin{tabular}{|c|c|c|}
\hline Author(s) & Benefits & Challenges \\
\hline $\begin{array}{l}\text { Bengali } \\
(2015)\end{array}$ & $\begin{array}{l}\text { Western Route: cheapest to } \\
\text { construct; jobs; national inte- } \\
\text { gration }\end{array}$ & $\begin{array}{l}\text { Eastern route: most expensive } \\
\text { to construct and can cause } \\
\text { political instability between } \\
\text { provinces; western and central } \\
\text { route: security threats }\end{array}$ \\
\hline Javaid (2016) & $\begin{array}{l}\text { Energy and infrastructure } \\
\text { projects; Gwadar port devel- } \\
\text { opment; FDI }\end{array}$ & $\begin{array}{l}\text { Indian threat; security con- } \\
\text { cerns }\end{array}$ \\
\hline Sial (2014) & $\begin{array}{l}\text { Change in Govt. unlikely } \\
\text { to reverse development under } \\
\text { CPEC; positive economic out- } \\
\text { look }\end{array}$ & $\begin{array}{l}\text { Political instability; economic } \\
\text { constraints; geostrategic dy- } \\
\text { namics; security threats }\end{array}$ \\
\hline $\begin{array}{l}\text { Abid \& Ash- } \\
\text { faq }(2015)\end{array}$ & $\begin{array}{l}\text { Economic development; } \\
\text { overcoming energy crisis; } \\
\text { infrastructure development; } \\
\text { poverty eradication; prosper- } \\
\text { ity }\end{array}$ & $\begin{array}{l}\text { External and internal threats; } \\
\text { political unrest; security; ad- } \\
\text { ministrative issues }\end{array}$ \\
\hline $\begin{array}{l}\text { Zhiqin \&Yang } \\
(2016)\end{array}$ & Source of potential synergy & $\begin{array}{l}\text { Security, terrorism and politi- } \\
\text { cal challenges; cultural differ- } \\
\text { ences and practices }\end{array}$ \\
\hline
\end{tabular}

\subsection{Cement industry of Pakistan}

The cement industry is one of the oldest industries in Pakistan, as the raw material limestone and clay is found in abundance in the country. Cement consumption is directly related to a nation's economic growth. Pakistan is the 5th largest exporter and 14th largest producer of cement, however, per capita consumption is low at $140 \mathrm{~kg}$ against the global average of $400 \mathrm{~kg}$ per capita Chhoangalia et al (2016). The annual installed cement production capacity of Pakistan is more than 45.6 million tons (APCMA, 2017c).

Business Review: (2017) 12(2):65-83 
During the interviews, details of which are presented in the next section, one of our interviewees indicated that cement's local demand is going to rise due to various in-progress or up-coming developmental projects besides CPEC. This is in line with the rise in Public Sector Development Program's (PSDP) budget allocations by $29 \%$ in 2016 (2017).

For this study, the cement plants closer to CPEC-ER were identified for further analysis. Table 3 lists these 19 plants with their installed capacities. For this research, only cement (exported through sea) and coal (imported for heating purposes in this industry) are considered. Pakistan exports cement to Afghanistan, India, Sri Lanka, Africa and the Middle East, for which both inland and sea transportation modes are utilized. However, cement exports are on the decline, Pakistan's total cement exports for 2016 are $13.5 \%$ of total installed capacity.

This study considers the export capacity through sea, which is around $6.3 \%$ of the total installed capacity (APCMA, 2017b). According to one of our interviews: cement in $50 \mathrm{~kg}$ bags is frequently loaded on 15,000 to 50,000 tons' vessels at the port. Cement is brought to the ports in cement bowsers with 50-55 tons' capacity. 75 tons' bulkers are used for exporting loose cement, however, this is the case with only one company in Pakistan, which also has loading infrastructure at the port. Special weather tight vessels are required for the export of loose bulk cement. This information becomes the input for our mathematical and simulation models.

Coal is consumed at a rate of approximately $150 \mathrm{~kg}$ for producing one ton of cement, therefore large quantities are required to be imported. The cement industry uses coal imported mostly from South Africa and Indonesia. Australian and Columbian coal is also used, however, its transportation costs are higher. Plants located in the north have to bear the costs of transporting coal from the ports which are in the south, as well as transporting cement for export to the ports. As per one interview, sometimes around 400 trucks worth of coal has to be transported from the port all the way to a cement plant in the northern part of the country.

\section{Research Methodology}

Quantitative model based descriptive research was carried out using the empirical data. We conducted six unstructured interviews, as part of the primary research, to collect data (operational details that were used as inputs for the employed quantitative methods) and facts from relevant experts. All the interviewees gave their consent for participation.

Inclusion criteria for purposive sampling was that the interviewee should be a senior professional associated with one of the following sectors: cement, logistics, port or highway. The interviewees included two participants from different cement companies, two government officials, one from highway management, one from port operations, and two from different logistics' companies.

The employed multi-method optimization strategy Watson (2013) started with mathematical modeling and the creation of a simulation As-Is model. The 
Table 3: Cement production capacity in tons of the selected 19 plants (APCMA, 2017a)

\begin{tabular}{lr}
\hline Name of cement plant & Annual capacity \\
\hline Askari Cement Nizampur & 1575000 \\
Askari Cement Limited Wah & 1102500 \\
Bestway Cement Limited Hattar & 1228500 \\
Bestway Farooqia Cement Limited Hattar & 1086750 \\
Dewan Hattar Cement Limited Hattar & 1134000 \\
Fecto Cement Limited - Sangjani & 819000 \\
Fauji Cement Company Limited Fateh Jang & 3433500 \\
Flying Cement Limited Lilla & 1197000 \\
Pioneer Cement Limited Khushab & 2030250 \\
Bestway Cement Limited Chakwal & 3600000 \\
Bestway-PakCem Company Limited Chakwal & 2047500 \\
Dandot Cement Limited Jehlum & 504000 \\
D.G.Khan Cement Limited Chakwal & 2110500 \\
GharibWal Cement Limited Jehlum & 2110500 \\
Lucky Cement Limited Indus Highway, & 3600000 \\
Dewan Hattar Cement Limited Dhabeji & 1764000 \\
Power Cement Limited Nooriabad Dadu & 945000 \\
Thatta Cement Limited Thatta & 488250 \\
Attock Cement Pakistan Hub Chowki Lasbela & 1795500 \\
Total & 32571750 \\
\hline
\end{tabular}

data collected from primary and secondary sources formed the input to the mixed-integer linear programming (MILP) model and the simulation model developed on Witness Simulation Software. A detailed and systematic modeling approach was followed to gradually develop a sound and sensible model. This ensures the model's accuracy as we steadily built the required complexity into the model Watson (2013).

The mathematical model was solved using the solver function of MS Excel, while, Witness simulation model was run to simulate a complete year. We verified and validated the models by presenting these models to the representatives of a cement and a logistics company. These manifestations invoked a deeper discussion on the effectiveness and efficiency of the models. Output data, the data of APCMA, are available, so simulation output was compared with these as well, as suggested by Kleijnen (1999). A What-If or To-Be model was then developed and simulated for improving the key outputs by proposing a new interchange on the CPEC-ER.

\section{CPEC's route optimization model}

The aim was to model the cement industry's scenario and we started by identifying the location of cement plants along the CPEC-ER. Two basic flows of the cement industry were recognized: (a) cement moving from plant ' $i$ ' to inter- 
change ' $\mathrm{l}$ ' and then to port ' $\mathrm{j}$ ' for export, as shown in figure 2, and; (b) imported coal moving from ports to plants, in the direction inverse of the cement flow.

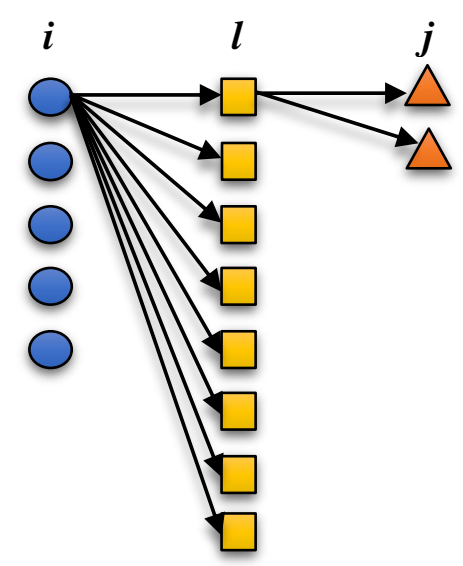

Fig2: Schematic model of cement flow

\subsection{Flow of cement}

Bowsers, with cement from the cement plants, should travel on local roads to the nearest (or cheapest to transport) interchange of CPEC-ER. Once on the highway they head for the ports (Karachi and Gwadar). As the inventory moves from the cement plant to the interchange and subsequently to the port, the model gives a sense of a multi-echelon model.

The MILP model, for the cement flow i.e. cement coming from plants to ports, is defined as:

minimize:

$$
\sum \cdot \sum \operatorname{dist}_{i l} f_{i l} K_{i} y_{i l}+\sum \cdot \sum \operatorname{dist}_{l j} f_{l j} x_{l j}
$$

subject to:

$$
\begin{gathered}
\sum x_{l j}=D_{j} ; \forall j \in J \\
\sum x_{l j} \leq \sum K_{i} y_{i l} ; \forall l \in L \\
\sum K_{i} \geq \sum D_{j}
\end{gathered}
$$




$$
\sum y_{i l}=1 ; \forall i \in I
$$

$y_{i l} \in 0,1 ; \forall i \in I, \forall l \in L$

$$
x_{l j} \geq 0 ; \forall l \in L, \forall j \in J
$$

$$
K_{i}, D_{j} \in \text { integer } ; \forall i \in I, \forall j \in J
$$

where $i$ is the source (cement plant or cluster of cement plants); $I$ is the set of $n$ sources; $l$ is the interchange on the CPEC-ER; $L$ is the set of $p$ interchanges; $j$ is the destination (port); $J$ is the set of $m$ destinations (set of two ports Karachi and Gwadar); $x_{a b}$ is the number of trucks (cement bowser) travelling from a to $\mathrm{b} ;$ dist $_{a b}=$ distance in kilometer from a to $\mathrm{b} ; f_{a b}$ is the fuel cost per km; $y_{i l}$ is a binary variable defining whether a cement bowser is travelling from source $i$ to an interchange $l$ or not; $K_{i}$ is $6.3 \%$ of the total capacity of a source $i$ in truckloads, and; $D_{j}$ is the demand of a destination $j$.

The objective function in equation (1) has two parts and it minimizes costs as a classic optimization objective function. The first part defines the cost of transporting cement from cement plants (or clusters) to the interchanges. A plant will send all its capacity $\left(K_{i}\right.$ or ceiling value of a plant's capacity in truckloads of cement) via only one interchange, the cheapest. The second part calculates the cost of transporting cement from the interchanges to the port.

Equations (2) to (8) are the constraints of the model. The number of trucks travelling from interchanges to ports must cover the export demand at ports, as defined by equation (2). Constraint (3) enforces that the number of trucks travelling from a specific interchange $l$ to all ports cannot exceed the cumulative capacity of those plants that shipped to $l$. Constraint (4) further emphasizes the fact that total cumulative demand of ports cannot exceed total cumulative capacity of the cement plants on the eastern route. Equation (5) and (6) enforce that each plant can send all its truckload material to the port through only one interchange. The model ends with non-negativity and integer constraints. The size of the model is: four functional, one binary, one non-negativity and one integer constraint, with 35 decision variables ( 25 for each combination of plant-interchange and 10 for each combination of interchange-port); as depicted by the mathematical derivative.

The cement plants on CPEC-ER are classified into five clusters as shown in figure 3. MS Excel produced the optimal solution i.e. the best combination of cement plants and interchanges, to achieve minimum fuel costs. Possible data of transportation costs (PKR), clusters' cement production capacity (trucks) and ports' demand (trucks) are shown in table 4. Comparing this table with the solution in table 5 , we observe that the model builds an optimal trade-off between transportation costs from clusters to interchanges and from interchanges to ports. The cost of this optimal solution, in table 5 for cement bowsers, is PKR 945.22 million. Interchange- 2 was not found attractive for any cement cluster.

Business Review: (2017) 12(2):65-83 


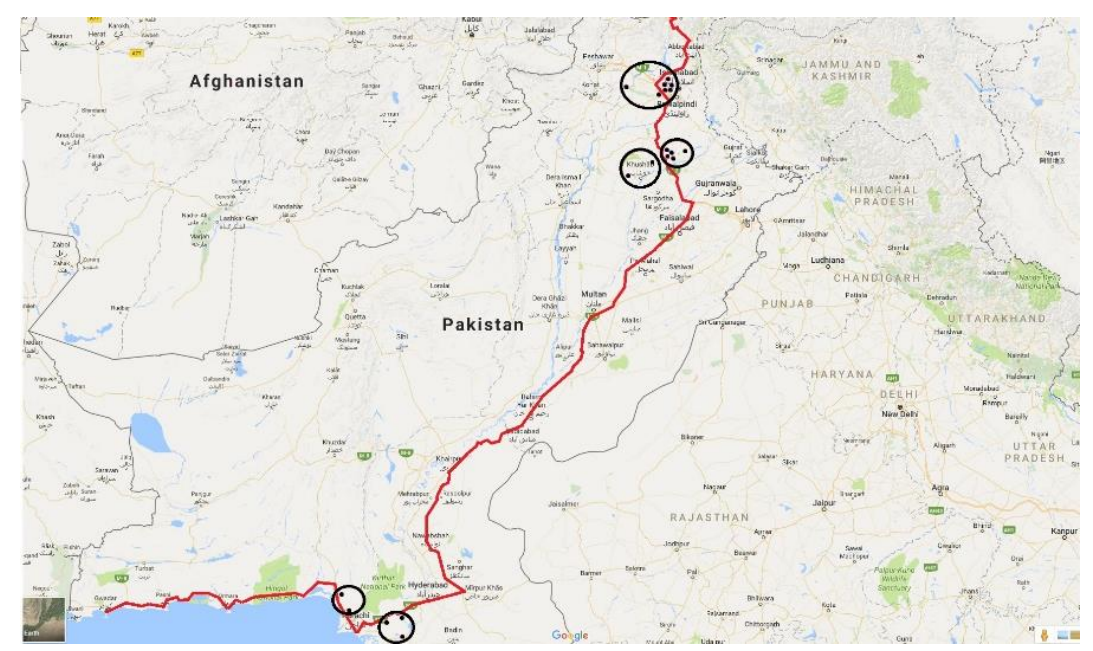

Fig3: Five cement clusters identified on CPEC's eastern alignment

4.2 Flow of coal

The same but reverse transportation model of the cement flow was used for coal, and therefore it is not presented here for brevity.

Table 4: Possible transportation cost (PKR) from cluster to interchange to port along with clusters' cement capacity (trucks) and port's cement demand (trucks)

\begin{tabular}{crrrrrrr}
\hline \multirow{2}{*}{ Interchange } & \multicolumn{4}{c}{ Cluster } & \multicolumn{3}{c}{ Port } \\
\cline { 2 - 8 } & \multicolumn{1}{c}{1} & \multicolumn{1}{c}{3} & \multicolumn{1}{c}{4} & \multicolumn{1}{c}{5} & \multicolumn{1}{c}{1} & \multicolumn{1}{c}{2} \\
\hline 1 & 517 & 3,564 & 3,096 & 27,837 & 30,083 & 24,948 & 36,216 \\
2 & 3,420 & 1,318 & 565 & 26,417 & 28,663 & 22,554 & 33,822 \\
3 & 4,698 & 686 & 846 & 20,592 & 22,838 & 22,068 & 33,336 \\
4 & 27,832 & 21,006 & 26,460 & 522 & 2,768 & 1,757 & 13,025 \\
5 & 30,384 & 23,558 & 29,012 & 3,074 & 216 & 562 & 10,800 \\
\hline Cap / Dem & 14,778 & 4,595 & 14,769 & 9,678 & 2,556 & 37101 & 9275 \\
\hline
\end{tabular}

\subsection{Simulation model}

Simulation packages are widely used as simulation bears the minimum cost of implementation Latif and Saunders (2010). Simulations are used to model current or improved scenario to attain process optimization before the model's implementation Kumar and Phrommathed (2006). Improving processes not only maximizes internal efficiency but also reduces extra-incurred costs, making the process more adaptable and comfortable for any user. 
Table 5: Routing of cement trucks from clusters to interchange to port

\begin{tabular}{cccccccc} 
& \multicolumn{4}{c}{ Cluster } & \multicolumn{3}{c}{ Port } \\
\cline { 2 - 8 } Interchange & 1 & 2 & 3 & 4 & 5 & 1 & 2 \\
\hline 1 & 1 & 0 & 0 & 0 & 0 & 14,778 & - \\
2 & 0 & 0 & 0 & 0 & 0 & 0 & - \\
3 & 0 & 1 & 1 & 0 & 0 & 19,364 & - \\
4 & 0 & 0 & 0 & 1 & 0 & 2,959 & 6,719 \\
5 & 0 & 0 & 0 & 0 & 1 & - & 2,556 \\
\hline
\end{tabular}

\subsubsection{Transportation in the cement industry}

The simulation model was designed on Witness simulation software which has the ability to model complex processes and operational tasks Lanner (2016). The simulation model reflects the logistics operations as discussed previously under the mathematical model; however, it only focuses on the export and import via Karachi, as Gwadar port is not currently catering to any cement exports or coal imports.

Following figure 3, average distance was computed (using (Google, n.d.)) from each cluster to its nearest interchange, as shown in table 6 . The route's alignment shown in figure 3 is indicative and alternatively the exact alignment hinted in figure 1 can be used in subsequent modeling.

\subsubsection{Aims of the model}

The purpose of this model is to gauge the impact of an interchange's location on CPEC-ER, on the transportation costs borne by the cement industry. For instance, what impact will the location of a new interchange have on the distances travelled and eventually the fuel costs? Such a model has direct utility for national highway management authorities. First hand data regarding average travelling times, average fuel consumption, number of trucks needed, specific coal demands and per ton transportation costs of company-owned or third-party logistics, were collected through interviews. 


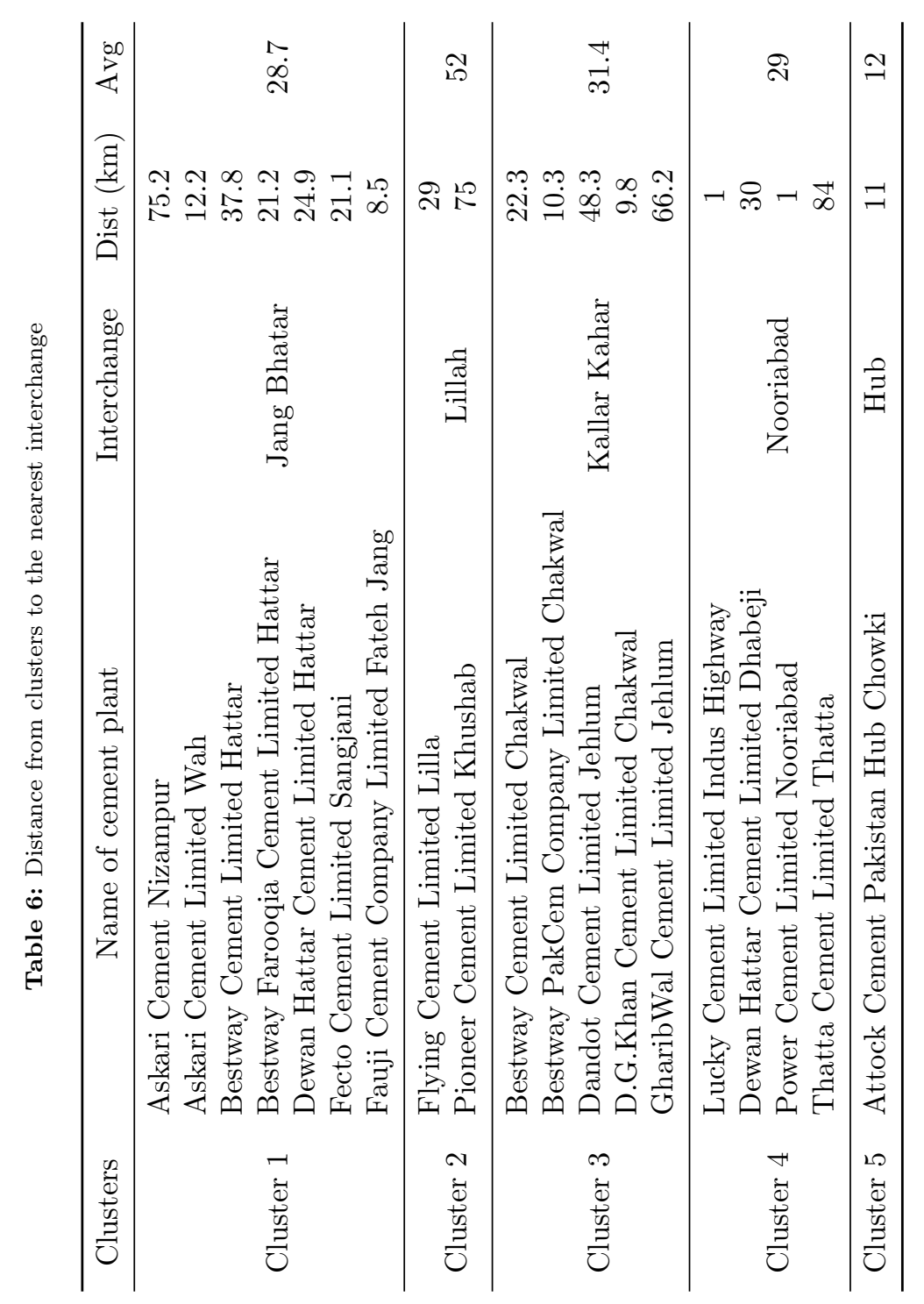




\subsubsection{Modelling the system}

Witness model is built using basic modeling elements. Details of the elements used are:

(1) Entity: Entities are elements that flow in a simulation model. Cement bowsers and coal trucks are entities in our model.

(2) Activity: It processes the entities flowing through it, i.e. it will perform some operations as desired. In this model interchanges and ports are activities.

(3) Paths: It shows the entity's flow and makes the model more interactive and realistic. Here the path is the CPEC-ER.

(4) Variable: It displays the data available in the model. Variables can be real or integer.

For developing a visual interactive system (VIS) in Witness, following elements are used in the basic model:

(1) Track: CPEC-ER track is modelled using path. Multiple paths represent the tracks between interchanges and this sequence develops the whole alignment. Cement bowsers or coal trucks travel along a path following speed-varying triangular distribution that has defined maximum and minimum speeds. This makes the model stochastic, representing the dynamic nature of the problem at hand. (2) Coal trucks and cement bowsers: Represented by an entity. The entity is created as per the cement or coal demand for a particular cement plant or port respectively.

(3) Total distance travelled: Calculated as each cement bowser /coal truck reaches destination.

(4) Fuel cost: Calculated as each cement bowser or coal truck reaches its destination. Average fuel consumption is four $\mathrm{km}$ per litre.

\subsubsection{As-Is and What-If scenarios}

Subsequently, an As-Is Model was developed and then a What-If or To-Be scenario was created and compared with the As-Is model. The simulation was made to run for one year to fulfill the complete annual demand and supply of cement and coal.

The As-Is scenario, focused on only seven interchanges: Hub, Nooriabad, Lillah, Kallar Kahar, Jang Bhatar, Khunjrab Pass and Kashghar. For the What-If scenario, another interchange Dhoki Punnun is added to answer: 'What-If we add this new interchange?' This interchange was proposed because it has a lower average distance from cement cluster 1 than Jang Bhatar, as shown in table 7.

The new proposed interchange improved the outputs of the model. Figure 4 and 5 show the results of the simulation. The What-If scenario was tested with only one new interchange, however, more scenarios and more industries can be added to bring more complexity into the model.

\section{Results and discussion}

The results of the As-Is scenario are shown in tables 8 and 9. Considering the number of trucks that entered and shipped, the transportation cost for the whole 
Table 7: Distance of the proposed interchange

\begin{tabular}{|c|c|c|c|c|c|}
\hline Plant & Cluster & Name of cement plant & $\begin{array}{l}\text { Proposed inter- } \\
\text { change }\end{array}$ & $\begin{array}{l}\text { Dist } \\
(\mathrm{km})\end{array}$ & $\overline{\mathrm{Avg}}$ \\
\hline 1 & & Askari Cement Nizampur & & 86 & \\
\hline 2 & & $\begin{array}{l}\text { Askari Cement Limited } \\
\text { Wah }\end{array}$ & & 18.1 & \\
\hline 3 & Cluster 1 & $\begin{array}{l}\text { Bestway Cement Limited } \\
\text { Hattar }\end{array}$ & Dhoki Pannun & 30 & 27.8 \\
\hline 4 & & $\begin{array}{l}\text { Bestway Farooqia Cement } \\
\text { Limited Hattar }\end{array}$ & $(33.69,72.74)$ & 18.5 & \\
\hline 5 & & $\begin{array}{l}\text { Dewan Hattar Cement } \\
\text { Limited Hattar }\end{array}$ & & 22.2 & \\
\hline 6 & & $\begin{array}{l}\text { Fecto Cement Limited } \\
\text { Sangjani }\end{array}$ & & 16.1 & \\
\hline 7 & & $\begin{array}{l}\text { Fauji Cement Company } \\
\text { Limited Fateh Jang }\end{array}$ & & 3.4 & \\
\hline
\end{tabular}

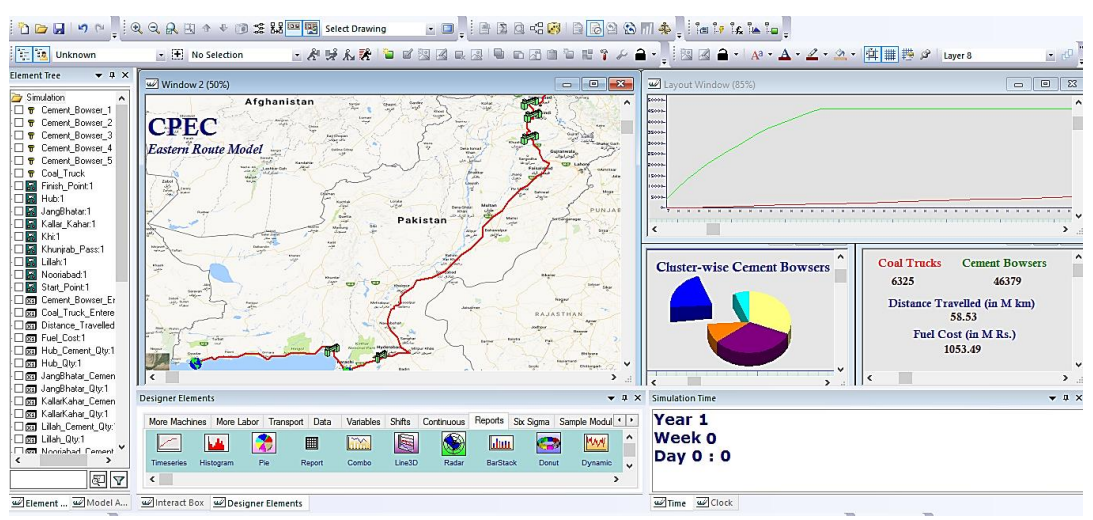

Fig4: CPEC-ER (As-Is) Witness Simulation Model: all values are for a year

year, of coal trucks and cement bowsers is PKR 1053.49 million with travelled distance of 58.53 million $\mathrm{km}$ (see figure 4). Furthermore, it can be seen that the longest average time (1.38 days) is taken by those cement bowsers that are south bound (i.e. coming from cluster-1) and the lowest (0.07 days or 1.7 hours) is taken by those coming from the port's neighboring city of Hub.

Table 9 depicts that transportation due to cement export makes the track between Nooriabad and Lillah interchanges to be the busiest track on the eastern route, as it was $95.42 \%$ busy. On the other hand, the track between Hub and Karachi was the least busy as Hub has lesser number of plants and it is closest to the port.

Same modeling procedure was repeated by adding an interchange Dhoki Punnun in the What-If scenario. This change reduced the average distance, as this interchange is closer to cluster 1 than the previous interchange. The results 


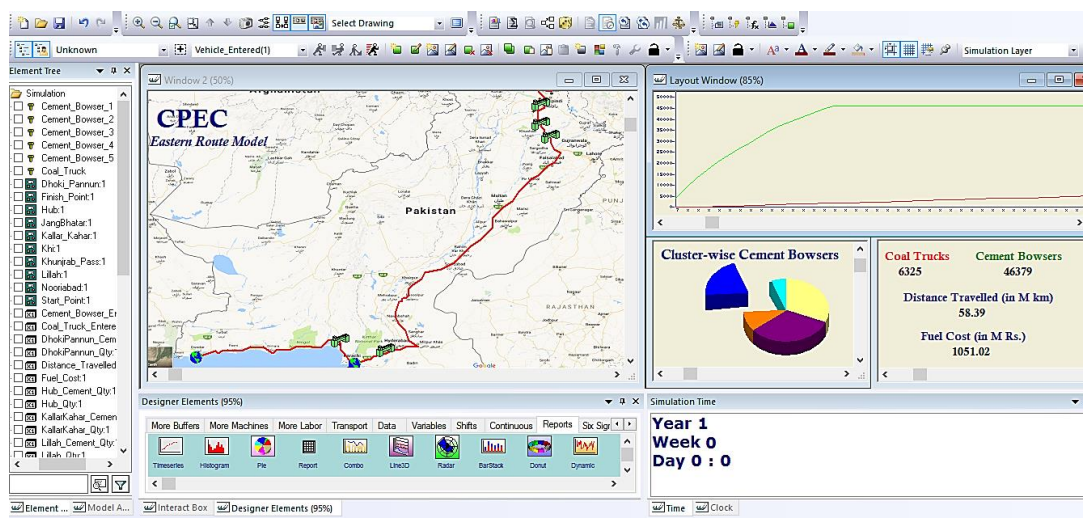

Fig5: CPEC-ER (What-If or To-Be) Witness Simulation Model: all values for a year

Table 8: Truck Statistics (As-Is version)

\begin{tabular}{lcccccc}
\hline \multirow{2}{*}{ Details } & \multirow{2}{*}{ Coal Trucks } & \multicolumn{5}{c}{ Cement Bowsers from } \\
\cline { 3 - 7 } & & Cluster-1 & Cluster-2 & Cluster-3 & Cluster-4 & Cluster-5 \\
\hline No. Entered & 6325 & 14778 & 4595 & 14769 & 9678 & 2559 \\
No. Shipped & 6325 & 14778 & 4595 & 14769 & 9678 & 2559 \\
Avg on Highway & 18.05 & 58.24 & 15.05 & 55.58 & 3.06 & 0.52 \\
Avg Time & 1 & 1.38 & 1.15 & 1.32 & 0.11 & 0.07 \\
\hline
\end{tabular}

Table 9: Route Statistics (As-Is version)

\begin{tabular}{lccccc}
\hline Details & $\begin{array}{l}\text { Karachi } \\
\text { Hub }\end{array}$ & $\begin{array}{l}\text { Karachi } \\
\text { Nooriabad }\end{array}$ & $\begin{array}{l}\text { Nooriabad } \\
\text { Lillah }\end{array}$ & $\begin{array}{l}\text { Lillah } \\
\text { KallarKahar }\end{array}$ & $\begin{array}{l}\text { KallarKahar } \\
\text { JhangBhatar }\end{array}$ \\
\hline Trucks In & 2908 & 49796 & 38799 & 33578 & 16794 \\
Trucks Out & 2908 & 49796 & 38799 & 33578 & 16794 \\
\% Busy & 5.52 & 95.12 & 95.42 & 92.46 & 58.8 \\
\% Idle & 94.48 & 4.88 & 4.58 & 7.54 & 41.2 \\
\hline
\end{tabular}

of this scenario are presented in tables 10 and 11.

For the proposed interchange in this What-If or To-Be scenario, the total transportation cost comes down to PKR 1051.02 million as shown in figure 5 . This minor change brought savings in cement industry's transportation costs to the tune of almost PKR 2.5 million.

On average, all the tracks in the As-Is analysis were busy $69.5 \%$ of the time (see table 7), whereas, in the What-If analysis they were busy $70.1 \%$ of the time (see table 9). This rise is because trucks now access the highway from a closer interchange and thus stay longer on the highway as compared to the previous model. This further increases the utilization of the highway. In the long run, a more complex model can be developed for bringing significant satisficing so that the inherent uncertainty in supply chain decisions can be minimized.

Business Review: (2017) 12(2):65-83 
Table 10: Truck Statistics (What-If version)

\begin{tabular}{lcccccc}
\multirow{2}{*}{ Details } & \multirow{2}{*}{ Coal Trucks } & \multicolumn{5}{c}{ Cement Bowsers from } \\
\cline { 3 - 7 } & & Cluster-1 & Cluster-2 & Cluster-3 & Cluster-4 & Cluster-5 \\
\hline No. Entered & 6325 & 14778 & 4595 & 14769 & 9678 & 2559 \\
No. Shipped & 6325 & 14778 & 4595 & 14769 & 9678 & 2559 \\
Avg on Highway & 18.68 & 62.9 & 15.05 & 55.58 & 3.06 & 0.52 \\
Avg Time & 1.03 & 1.49 & 1.15 & 1.32 & 0.11 & 0.07 \\
\hline
\end{tabular}

Table 11: Route Statistics (What-If version)

\begin{tabular}{lccccc}
\hline Details & $\begin{array}{l}\text { Karachi } \\
\text { Hub }\end{array}$ & $\begin{array}{l}\text { Karachi } \\
\text { Nooriabad }\end{array}$ & $\begin{array}{l}\text { Nooriabad } \\
\text { Lillah }\end{array}$ & $\begin{array}{l}\text { Lillah } \\
\text { KallarKahar }\end{array}$ & $\begin{array}{l}\text { KallarKahar } \\
\text { DhokiPannun }\end{array}$ \\
\hline Trucks in & 2908 & 49796 & 38799 & 33578 & 16794 \\
Trucks out & 2908 & 49796 & 38799 & 33578 & 16794 \\
\% Busy & 5.52 & 95.12 & 95.42 & 92.49 & 62.16 \\
\% Idle & 94.48 & 4.88 & 4.58 & 7.51 & 37.84 \\
\hline
\end{tabular}

\subsection{Qualitative data analysis}

Stimulating discussions took place during the six interviews. The recurring findings were:

(1) Non existent use of quantitative approaches in decision making in Pakistan;

(2) Cement companies are not completely satisfied with the locations of the proposed interchanges;

(3) Sufficient and accurate congestion data are not available;

(4) Scarce quantitative research discussing the positive (constructive) or negative (cannibalizing) effects, on the Gwadar Port, of other developments in Pakistan;

(5) Land acquisition and construction of interchanges is easier to do in one province than others;

(6) In developing countries, it is worthwhile to keep various non-critical functions (such as transportation) in-house as these usually decrease costs and increase competitive advantage;

(7) Land costs decline where highways are built and rise where interchanges are built;

(8) There is no eastern route, rather there is an eastern alignment that uses PKM.

\section{Conclusion and future research}

The objective of this study was to present an application of the quantitative multi-method approach for optimizing China-Pakistan Economic Corridor's (CPEC) eastern route (Khunjrab to Gwadar through Peshawar to Karachi Motorway) by proposing better choice and location of interchanges. It can further 
validate the already suggested interchanges (in the CPEC plan). The cement industry was selected for building the case study.

For this purpose, we developed a mixed-integer linear programming (MILP) model, followed by discrete-event simulation. Data was gathered from secondary sources along with six interviews. The mathematical model was tested in MS Excel, which suggested the optimal combination of clusters, interchanges and ports. The As-Is model was then developed on Witness Simulation Software and once it was validated, a What-If or To-Be model was created. The What-If model showed improvements in the outputs (distance travelled and fuel costs) when one new interchange was proposed. However, further design of a complicated model with multiple inputs is necessary before the implementation of the What-If scenario.

Further areas of research include developing more What-If scenarios on Witness, bringing the local consumption of cement and clinker into the scope of the model as opposed to using only exported cement, incorporating more inputs and outputs of the cement industry, and, taking applicable taxes, tariffs and tolls into account. This study can be extended by collecting data for industries other than cement to develop a more complex model. One can test models with other objective functions, such as minimizing travelling time, third party (3PL) or fourth party logistics' (4PL) costs, accidents and congestion.

\section{References}

2016a. Building the Impossible. Shanghai Business Review. February - March 2016 ed.

2016b. Gwadar to get first SEZ under CPEC. Dawn, January 28, 2016.

2016c. Pak's strategic Gwadar port opens USD 46-billion China-Pakistan Economic Corridor. Z-News, November 13, 2016.

2017. China to build highway network for improved links with Pakistan. The Express Tribune, February 7, 2017.

2017. Budgeted PSDP Allocation Trend [Online]. Available: http://par.com.pk/ news/budgeted-psdp-allocation-trend [Accessed January 2017].

Abid, M. \& Ashfaq, A. 2015. CPEC: Challenges and opportunities for Pakistan. Journal of Pakistan Vision, 16, 142-169.

Ahmed, R. \& Mustafa, U. 2016. Impact of CPEC Projects on Agriculture Sector of Pakistan: Infrastructure and Agricultural Output Linkages. In: (PSDE), T. P. S. O. D. E. (ed.) 32nd Annual General Meeting and Conference. Islamabad, Pakistan.

APCMA. 2017a. Historical Analysis of Cement Production Capacity \& Despatches (Operational Units Data) [Online]. Available: http://www.apcma.com/data history.html [Accessed January 2017].

APCMA. 2017b. Monthly Analysis (Local and Export Despatches) [Online]. Available: http : //www.apcma.com/datamonthly1617.html [Accessed January, 2017].

APCMA. 2017c. Statement of Installed Production Capacity [Online]. Available: http : //www.apcma.com/dataproductioncapacity.html [Accessed Jan- 
uary 2017].

Bengali, K. 2015. China Pakistan Economic Corridor? The Route Controversy. Chief Minister's Policy Reform Unit, Government of Balochistan.

Bollapragada, R., Poduval, S., Bingi S, C. \& Brahmbhatt, B. 2016. Solving Traffic Problems in the State of Kerala, India: Forecasting, Regression and Simulation Models. Vikalpa, 41, 325-343.

Calabrese, J. 2014. Balancing on 'the Fulcrum of Asia': China's Pakistan Strategy. Indian Journal of Asian Affairs, 27/28, 1-20.

Chhoangalia, T. I., Masood, M. \& Hussain, L. 2016. Cement Industry. JCR-VIS Sector Update.

Finance, M. O. 2016. Transportation and Communication. Pakistan Economic Survey 2015-16.

Gonzalez Velarde, J. L., Camacho-Vallejo, J.-F. \& Pinto Serrano, G. 2015. A Scatter Search Algorithm for Solving a Bilevel Optimization Model for Determining Highway Tolls. Computacin y Sistemas, 19, 05-16.

Google. n.d. Google Maps [Online]. Available: https://www.google.com/maps [Accessed January 10, 2017].

Javaid, U. 2016. Assessing CPEC: Potential Threats and Prospects. Journal of the Research Society of Pakistan, 53.

Kleijnen, J. P. Validation of models: statistical techniques and data availability. Proceedings of the 31st conference on Winter simulation: Simulation-a bridge to the future-Volume 1, 1999. ACM, 647-654.

Kumar, S. \& Phrommathed, P. 2006. Improving a manufacturing process by mapping and simulation of critical operations. Journal of Manufacturing Technology Management, 17, 104-132.

Lanner, T. G. 2016. Witness [Online]. Available: www.lanner.com.

Latif, M. \& Saunders, C. 2010. A Traditional Logistics Problem. International Journal of Engineering, 2, 161-170.

Li, Y.\& Chow, A. H. 2015. Optimisation of motorway operations via ramp metering and variable speed limits. Transportation planning and technology, 38, 94-110.

Market Research Provider, E. I. 2017. Pakistan: Country Profile

Markey, S. D. \& West, J. 2016. Behind China's Gambit in Pakistan. Council on Foreign Relations.

Mitra, S. 2016. Analysis of Truck Accidents Using Structural Equation Models. Transportation Journal, 55, 382-399.

Mohmand, Y. T. \& Wang, A. 2013. Weighted complex network analysis of Pakistan highways. Discrete Dynamics in Nature and Society, 2013.

Mudroch, A. 1999. Planning and management of lakes and reservoirs, an integrated approach to Eutrophication. Shiga: UNEP International Environmental Technology Centre.

NHA. 2017. Map of National Highway Network [Online]. Available: http://nha.gov. pk/wp-content/themes/nha/images/map-full.jpg [Accessed January 2017].

Prodhon, C. \& Prins, C. 2014. A survey of recent research on location-routing problems. European Journal of Operational Research, 238, 1-1

Ramay, S. A. 2016. China Pakistan Economic Corridor: A Chinese Dream Being Materialized Through Pakistan. 
Shafahi, Y. \& Bagherian, M. 2013. A customized particle swarm method to solve highway alignment optimization problem. Computer Aided Civil and Infrastructure Engineering, 28, 52-67.

Sheu, J. B. \& Kundu, T. 2017. Forecasting time-varying logistics distribution flows in the One Belt-One Road strategic context. Transportation Research Part E: Logistics and Transportation Review.

Sial, S. 2014. The China-Pakistan Economic Corridor: an assessment of potential threats and constraints. Conflict and Peace Studies, 6, 24.

Watson, M., Lewis, S., Cacioppi, P. \& Jayaraman, J. 2013. Supply chain network design: applying optimization and analytics to the global supply chain, Pearson Education.

Zhang, R. \& Shi, G. 2016. Social impacts assessment for China-Pakistan Economic Corridor investment activities. IAIA-16. Aichi-Nagoya, Japan.

Zhiqin, S. \& Yang, L. 2016. The Benefits and Risks of the China-Pakistan Economic Corridor [Online]. Carnegie-Tsinghua Centre for Global Policy. Available: http://carnegietsinghua.org/2016/12/21/benefits-and-risksofchinapakistan economiccorridorpub-66507 [Accessed January 2017]. 